Undas Vol 12. , Nomor 1, Juni 2016 : 97--109

\title{
TATANGAR BANJAR SEBAGAI EKSPRESI SISTEM KOGNISI MASYARAKAT BANJAR
}

"Tatangar Banjar Expression Systems Society Cognition"

\author{
Sri Wahyu Nengsih
}

\author{
Balai Bahasa Kalimantan Selatan \\ Jalan Jenderal Ahmad Yani Km 32,2, Loktabat, Banjarbaru 70712 Kalimantan Selatan \\ Telepon (0511) 4772641, Pos-el: sriwahyu81@rocketmail.com
}

\begin{abstract}
Abstrak: Tatangar termasuk tradisi lisan Banjar tentang sebuah firasat yang menandakan sesuatu. Tatangar Banjar memiliki sistem kognisi yang mengkonstruksi pola hidup dan pola pikir masyarakat Banjar sebagai masyarakat pemilik tradisi lisan tersebut. Penelitian ini membahas tentang "Tatangar Banjar sebagai Ekspresi Sistem Kognisi Masyarakat Banjar". Tujuan dari penelitian ini untuk mendeskripsikan ekspresi sistem kognisi masyarakat Banjar dalam tatangar Banjar. Penelitian ini merupakan penelitian kualitatif dengan menggunakan metode deskriptif. Teknik pengumpulan data yang digunakan adalah studi pustaka. Data bersumber pada buku Tatangar atau Wahana Banjar tahun 2009 yang ditulis oleh Rissari Yayuk, dkk dan diterbitkan oleh Balai Bahasa Banjarmasin. Hasil penelitian ini akan diketahui tentang gambaran ekspresi sistem kognisi dalam tatangar Banjar yang ditunjukkan dalam sistem mata pencaharian, kepercayaan, organisasi sosial atau pranata sosial, perlindungan, makan atau kuliner, kesenian, dan daur hidup yang ada pada masyarakat Banjar
\end{abstract}

Kata kunci: Tatangar, sistem kognisi, masyarakat Banjar

Abstract: Tatangar including oral tradition Banjarese on a hunch that signifies something. Tatangar Banjar has a system of cognition that constructing patterns of life and mindset of the people as a community Banjarese owner of the oral tradition. This study discusses the "Tatangar Banjar Expression Systems Society Cognition". The purpose of this study to describe the expression describing cognition system in tatangar Banjarese community. This study is a qualitative study using descriptive methods. Data collection techniques used is literature. Data referred to the Tatangar or wahana Banjar in 2009 written by Rissari Yayuk, et al and published by Balai Bahasa Banjarmasin. The results of this study will be known about the expression of an idea of cognition in tatangar Banjar system that shows livelihoods, beliefs, social organizations or social institutions, protection, dining or culinary, arts, and life cycle of the community Banjarese.

Key words: Tatangar, cognition system, community Banjar.

\section{PENDAHULUAN}

Masyarakat Banjar memiliki kebudayaan sebagai identitas kedaerahannya. Bagian kebudayaan tersebut termasuk folklor atau tradisi lisan di dalamnya. Tradisi lisan terbentuk dari perpaduan cipta, rasa, dan karsa yang merupakan hasil interaksinya dengan lingkungan di sekitarnya. Lingkungan yang dimaksud, baik itu lingkungan fisik maupun lingkungan sosial. Itulah sebabnya tradisi lisan 
kaya akan berbagai pengalaman dengan berbagai macam kearifan lokal di dalamnya.

Tradisi lisan yang terdapat dalam masyarakat Banjar memiliki keberagaman. Keragaman tradisi lisan masyarakat Banjar, salah satunya adalah tatangar Banjar. Tatangar merupakan tradisi lisan yang termasuk takhyul dalam bentuk kalimat pernyataan yang menyimbolkan atau menandakan sesuatu (Yayuk,dkk.2009:3). Tanda, ciri, atau simbol yang dilihat, dialami atau dirasa oleh pelaku sebagai sebuah tatangar dianggap sebagai suatu firasat atau pertanda. Bagi orang Banjar, tanda, ciri, atau simbol tersebut memiliki makna tertentu. Contohnya, pabila baras dipadaringan dihurung samut, cagar harga baras handak naik. 'Apabila beras ditempat beras banyak semutnya, nanti harga beras akan naik'.

Tatangar Banjar terus bertahan dalam kepercayaan masyarakat Banjar. Tatangar tersebut merupakan bagian dari khasanah kearifan lokal masyarakat Banjar. Tatangar Banjar memiliki suatu sistem kognisi yang mengkontruksi pola hidup dan pola pikir masyarakat Banjar sebagai pemilik tradisi lisan tersebut. Hal tersebut berarti tatangar Banjar mengandung nilai-nilai moral dan adab yang ada pada masyarakat Banjar.

Namun, sesuai perkembangan zaman bukan tidak mungkin akan melenyapkan keberadaan tatangar dari masyarakat Banjar. Tidak dapat dipungkiri, di era modern seperti ini tatangar Banjar dianggap sesuatu yang remeh. Sebagai sebuah kepercayaan rakyat atau takhyul, tatangar Banjar dianggap tidak masuk akal sehingga secara ilmiah tidak dapat dipertanggungjawabkan. Hal tersebut memang sungguh disayangkan. Padahal tatangar sebagai sebuah tradisi lisan Banjar seharusnya terus dipertahankan keberadaaannya sebagai warisan luhur generasi terdahulu.
Berdasarkan uraian tersebut, peneliti merasa tertarik untuk menjadikan tatangar Banjar ini sebagai objek penelitian, terutama untuk mengetahui sistem kognisinya. Penelitian mengenai Tatangar Banjar, sudah pernah dilakukan oleh Rissari Yayuk (2010) yang berjudul "Tatangar Banjar". Penelitian tersebut membahas tentang tatangar Banjar, klasifikasi, dan makna tatangar Banjar.

Adapun penelitian mengenai sistem kognisi dalam sebuah tradisi lisan memang bukan sebuah hal yang baru. Yudi Handoko Himawan (2013) pernah meneliti sistem kognisi dalam tradisi lisan berjudul "Lelaq sebagai Cermin Sistem Kognisi Masyarakat Sasak". Penelitian tersebut membahas sistem kognisi masyarakat Sasak Nusa Tenggara Barat dalam tradisi lisan lelaq berdasarkan kata pembentuknya. Namun sepengetahuan peneliti, penelitian mengenai “Tatangar Banjar sebagai Ekspresi Sistem Kognisi Masyarakat Banjar" ini belum pernah dilakukan. Berbeda dengan penelitian sebelumnya, penelitian ini akan membahas ekspresi sistem kognisi masyarakat Banjar yang ada dalam tatangar Banjar.

Penelitian ini membahas masalah tentang "Tatangar Banjar sebagai Ekspresi Sistem Kognisi Masyarakat Banjar". Tujuan dari penelitian ini untuk mendeskripsikan ekspresi sistem kognisi masyarakat Banjar dalam tatangar Banjar.

\section{KERANGKA TEORI}

Kebudayaan tercipta dari sebuah hasil pikiran dan perasaaan yang dirasakan oleh manusia. Hal tersebut berarti kebudayaan sebagai proyeksi kehidupan manusia yang sifatnya tidak terbatas dan kompleks. Hatmiati (2016: 53) menjelaskan bahwa budaya berkaitan dengan kegiatan masyarakat seharihari yang membentuk prilaku, tetapi tidak tertanam secara permanen. 
Folklor sebagai bagian dari kebudayaan tumbuh mewarnai kehidupan masyarakat Banjar. Folklor adalah sebagian kebudayaan suatu kolektif yang tersebar dan diwariskan turun menurun secara lisan atau melalui suatu contoh yang disertai dengan gerak isyarat atau alat pembantu pengingat (Danandjaja,1982:12). Fungsi folklor menurut Bascom (dalam Danandjaja, 1982:19) ada empat, yaitu: a) sebagai sistem proyeksi, yaitu sebagai alat pencermin angan-angan suatu kolektif, b) sebagai pengesahan pranata-pranata dan lembaga-lembaga kebudayaan; c) sebagai alat pendidikan anak, dan d) sebagai alat pemaksa dan pengawas agar norma-norma masyarakat akan selalu dipatuhi anggota kolektifnya.

Penyebaran folklor pada umumnya melalui tutur kata atau lisan; itulah sebabnya ada yang menyebutnya sebagai tradisi lisan. Sebuah tradisi lisan akan bertahan dan dipakai oleh masyarakat pemiliknya selama mereka merefleksikan tradisi tersebut dalam kehidupan sehari-hari (Hatmiati,2016:4). Tradisi lisan adalah wacana yang diucapkan atau disampaikan secara turun temurun, ada yang lisan dan yang beraksara, dan disampaikan secara lisan. Namun, penyampaian tradisi lisan ini tidak hanya berupa kata-kata, tetapi juga gabungan antara kata-kata dan perbuatan tertentu yang menyertai kata-kata tersebut (Pudentia, 2007:27).

Tradisi lisan sebagai bagian dari kebudayaan kreatif mengandung berbagai hal mengenai hidup dan kehidupan masyarakat pemiliknya. Tradisi lisan yang dimiliki oleh masyarakat Banjar, diantaranya adalah tatangar Banjar. Tatangar Banjar sebagai bagian dari tradisi lisan diturunkan dari ke mulut ke mulut atau secara lisan. Tatangar merupakan tradisi lisan yang termasuk takhyul dalam bentuk kalimat pernyataan yang menyimbolkan atau menandakan sesuatu
(Yayuk, 2009:3). Hapip (2008:186) yang mengatakan bahwa tatangar berarti alamat, tanda-tanda akan terjadinya sesuatu peristiwa. Selanjutnya, Mugeni, dkk. mengatakan bahwa tatangar berarti firasat, pertanda akan terjadinya sesuatu peristiwa. Hal tersebut berarti tanda, ciri, atau simbol yang dilihat, dialami atau dirasa oleh pelaku sebagai sebuah tatangar dianggap sebagai suatu firasat atau pertanda terjadinya suatu peristiwa. Bagi orang Banjar, tanda, ciri, atau simbol tersebut memiliki makna tertentu. Contohnya, pabila baras dipadaringan dihurung samut, cagar harga baras handak naik. 'Apabila beras ditempat beras banyak semutnya, nanti harga beras akan naik'.

Tatangar Banjar lahir dari sebuah pengalaman yang menjadi sebuah pengetahuan kolektif masyarakat Banjar. Oleh karenanya, tatangar Banjar sebagai sebuah ekspresi kognisi masyarakat Banjar. Kognisi diartikan sebagai kegiatan atau proses mengenali sesuatu melalui pengalaman sendiri. Bisa juga diartikan proses penafsiran dan pengenalan lingkungan oleh seseorang, atau diartikan sebagai hasil pemerolehan pengetahuan (KBBI, 2002:579). Turmuzi (2011) memaparkan alam pikiran mistis sangat menjiwai (mendasari) tradisi lisan masyarakat Indonesia sejak zaman dahulu sampai sekarang. Cara masyarakat menjelaskan atau memahami realitas dihubungkan dengan hal mistis, bukan merupakan suatu kesengajaan untuk mengacaukan fakta dengan khayalan, tetapi memang merupakan suatu cara dalam menangkap realitas sesuai dengan alam pikiran mereka. Saputra (2013: 246) memaparkan bahwa masyarakat merasakan idiom-idiom setempat, yang dalam perkembangannya diramu dengan wacana relegius dari tradisi agama tertentu, dapat menyatu dengan niat dalam benak (kognisi). 
Dapat disimpulkan, bahwa ekspresi sistem kognisi dalam tatangar Banjar menunjukkan konstruksi pola hidup dan pola pikir masyarakat Banjar sebagai pemilik tradisi lisan yang lahir dari sebuah pengalaman kemudian menjadi sebuah pengetahuan kolektif masyarakat Banjar dengan dipengaruhi oleh khayalan/hal mistis dan unsur relegius dari agama tertentu.

\section{METODE PENELITIAN}

Penelitian ini merupakan penelitian kualitatif dengan menggunakan metode deskriptif. Penelitian kualitatif adalah prosedur penelitian yang menghasilkan data deskriftif berupa kata-kata tertulis atau lisan tentang orang-orang dan prilaku yang diamati (Moleong,2002:4). Danandjaya (1998:57) menyatakan bahwa penelitian yang berhubungan dengan folklor dapat diteliti secara holistik, dalam arti pada waktu menganalisis dapat dikaitkan dengan latar belakang dan konteks kebudayaan folklor bersangkutan.

Teknik pengumpulan data yang digunakan adalah studi pustaka. Data bersumber pada buku Tatangar atau Wahana Banjar oleh Yayuk, dkk (2009) dan diterbitkan oleh Balai Bahasa Banjarmasin. Data dalam penelitian ini adalah tatangar Banjar yang mengekspresikan sistem kognisi masyarakat Banjar di sumber data. Beberapa tatangar tersebut dipilih dan diklasifikasikan sesuai dengan masalah yang dibahas dalam penelitian ini.

\section{ANALISIS DAN PEMBAHASAN}

Tatangar Banjar memiliki suatu sistem kognisi yang mengkontruksi pola hidup dan pola pikir masyarakat Banjar sebagai pemilik tradisi lisan tersebut.
Sistem kognisi dalam tatangar Banjar lahir dari sebuah pengalaman yang menjadi sebuah pengetahuan kolektif sebagai bagian kearifan lokal masyarakat Banjar.

Gambaran tatangar Banjar sebagai ekspresi sistem kognisi ditunjukkan dari sistem mata pencaharian, kepercayaan, organisasi sosial atau pranata sosial, perlindungan, makan atau kuliner, kesenian, dan daur hidup yang ada pada masyarakat Banjar. Berikut gambaran"Tatangar Banjar sebagai Ekspresi Sistem Kognisi Masyarakat Banjar".

\section{Sistem Mata Pencaharian}

Dalam tatangar Banjar menunjukkan adanya ekspresi sistem kognisi berkaitan dengan sistem mata pencaharian masyarakat Banjar, yaitu.

\section{a. Pertanian}

Dalam tatangar Banjar, masyarakat Banjar mengandalkan sektor pertanian sebagai mata pencahariannya. Pertanian yang ditemukan dalam tatangar Banjar mengenai bercocok tanam di sawah, bercocok tanam buahbuahan, dan bunga-bungaan. Simak kutipan berikut.

\section{Tang tangir babunyi, tandanya lagi musim katam \\ 'Tiba-tiba tangir berbunyi, tandanya musim panen' (hlm.20)}

Kutipan di atas mengenai jika tibatiba serangga kecil yang bernama tangir berbunyi menandakan musim panen tiba. Hal tersebut merupakan tandatanda alam dari serangga bernama tangir yang dipergunakan sebagai pengetahuan para petani untuk mengetahui masa panen padi. Ketika suara tangir terdengar sahut menyahut, 
para petani bersiap-siap untuk memanen padi. Pekerjaan tersebut biasanya dilakukan dengan bergotongroyong. Gotong royong masyarakat Banjar pada kegiatan menanam dan memanen padi dinamakan dengan baarian atau bahandipan. Baarian/bahandipan dilakukan bergantian di sawah peserta gotong royong tersebut. Baarian dipakai untuk gotong royong di daerah persawahan pasang surut dan daerah dataran tinggi. Sedangkan, bahandipan dipakai untuk istilah daerah batang banyu atau tepi sungai besar (Ideham, dkk.2005:186).

Baarian/bahandipan mengandung nilai-nilai kearifan lokal mengenai hubungan dengan sesama manusia. Nilai-nilai tolong menolong kepada sesama manusia patut untuk dipertahankan, jangan sampai terkikis oleh sikap individualisme. Tidak bisa dipungkiri kemajuan zaman telah membawa dampak semakin meluasnya sikap individualisme manusia. Sikap individualisme tersebut tentu akan menjauhkan nilai-nilai tolong menolong termasuk di dalamnya tradisi baarian.

Tanda alam lain dalam pertanian yang terdapat pada tatangar Banjar adalah tentang keberadaan banyaknya gondong di persawahan. Berikut kutipannya.

Bila tang kalambuai banyak di pahumaan, tandanya musim hujan tiba 'Bila tiba-tiba gondong banyak di sawah, tandanya musim hujan tiba'.

Tatangar di atas memaparkan jika banyak gondong di sawah, menandakan musim hujan tiba. Gondong atau kalambuai merupakan hewan yang banyak ditemukan di sawah saat musim hujan tiba. Saat banyak gondong inilah, biasanya para petani memulai masa tanam padi di sawahnya. Pengetahuan kolektif berupa tanda alam adanya gondong sebagai saat yang tepat untuk memulai masa tanam masih dilakukan oleh para petani hingga saat ini. Pada masa tanam, baarian secara bergantian dilakukan oleh para petani di sawahnya masing-masing.

Masyarakat Banjar dalam tatangar menandai datangnya kemarau dengan melihat apabila pohon ambawang berbunga. Berikut kutipannya.

Bila hambawang bakambang, tandanya musim kamarau datang

'Bila ambawang berbunga, tandanya musim kemarau tiba'

Kutipan tersebut memaparkan tatangar Banjar tentang pohon dari buah ambawang yang apabila berbunga menandakan musim kemarau telah tiba. Saat kemarau, tentu bukan waktu yang baik untuk bercocok tanam. Pertanda alami tersebut tentu sangat membantu para petani untuk menentukan langkah yang tepat dilakukan agar tanamannya tetap tumbuh subur saat musim kemarau. Hal tersebut karena saat kemarau jarang terjadi hujan, sehingga tanaman cenderung kekurangan air.

Tatangar ini memiliki nilai kearifan mengenai hubungan manusia dengan lingkungannya dalam hal ini berupa tanaman. Kearifan menjaga keberlangsungan hidup tanaman sangat baik bagi kehidupan. Tanaman ambawang menghasilkan buah yang dapat dimakan oleh manusia. Tanaman tersebut juga menyerap berbagai polutan berbahaya di udara, kemudian menghasilkan oksigen yang digunakan makhluk hidup untuk bernafas. Semakin banyak tanaman, maka 
semakin baik manfaatnya bagi kehidupan.

Tatangar tersebut sekaligus menunjukkan pertanian di Kalimantan Selatan tidak hanya berkisar tanaman padi di sawah, ada pula pertanian buahbuahan. Buah-buahan yang ditanam contohnya ialah ambawang. Ambawang bentuknya seperti mangga dengan harum menyengat dan rasanya sedikit getir. Selain tanaman buah, komiditi pertanian di Kalimantan Selatan ialah bunga, contohnya bunga mawar. Hal tersebut terdapat pada tatangar berikut.

Bila ada kambang mawar di muka rumah, tanda parajakian

‘Bila ada bunga mawar di muka rumah, tanda murah rezeki'

Tatangar tersebut memaparkan bila ada bunga mawar di depan rumah, maka tandanya pemilik rumah murah rezekinya atau melimpah rezekinya. Tatangar tersebut mengisyaratkan bahwa bunga mawar bagus untuk di tanam. Bunganya yang cantik dan baunya yang harum menjadikan bunga mawar bernilai jual menjanjikan. Di daerah Tunggul Irang misalnya, bunga ini dibudidayakan untuk dijual. Kerajinan ronce bunga untuk hiasan pengantin menghasilkan pundi-pundi rezeki yang tidak ada matinya.

\section{b. Perikanan}

Selain bidang pertanian, mata pencaharian masyarakat Banjar yang lain ialah perikanan. Hal tersebut tampak pada beberapa tatangar berikut.

Bila tang sumur banyak iwaknya, tanda cagaran banyak razaki

'Bila tiba-tiba sumur banyak ikannya, tandanya akan banyak rezeki'
Tatangar di atas memaparkan apabila sumur banyak ikannya, tanda akan banyak rezeki. Dalam konteks ini, ikan dianggap sebagai rezeki. Oleh karena itu, apabila ikan yang di dapat banyak berarti rezeki yang diperoleh melimpah.

Di Kalimantan Selatan, memang terdapat kebiasaan membuat jebakan ikan dalam bentuk sumur yang disebut dengan istilah sumur paiwakan. Sumur ini dibuat di daerah rawa. Saat musim kemarau menyebabkan berkurangnya air, ikan akan masuk ke sumur itu dan menjadikannya tempat berkembang biak. Ikan-ikan di sumur itu akan ditangkap menggunakan alat penciduk, bernama halawit dan tanggung. Bila ikan yang diperoleh banyak, pemilik sumur paiwakan selain untuk dikonsumsi sendiri, ikan tersebut akan dijual sebagai sumber pendapatan keluarga.

Bila tang ada awan manyarupai galumbang, tandanya baik untuk malaut

‘Bila tiba-tiba ada awan manyerupai gelombang, tandanya baik untuk melaut'.

Tatangar tersebut memaparkan awan menyerupai gelombang, yang menandakan baik untuk melaut. Tatangar itu diperuntukkan untuk para nelayan yang biasa ke laut untuk mencari ikan. Pertanda alam tersebut tentu menjadi pengetahuan penting bagi para nelayan sebagai panduan untuk melaut.

Tatangar Banjar tersebut memiliki kearifan lokal yang berhubungan dengan lingkungan berupa hubungan laut dan manusia. Laut tanpa badai merupakan sahabat manusia. Laut tanpa badai memudahkan manusia dalam berpergian dan menangkap ikan. Oleh karenanya, penting sekali pengetahuan 
untuk mengetahui tanda-tanda di alam sebelum melaut.

\section{c. Mengandalkan hutan}

Tatangar Banjar yang berhubungan dengan hutan seperti pada kutipan berikut.

Bila tatamu tikus putih dalam hutan, tandanya apa nang handak kita gawi bakalan lancar

'Bila bertemu tikus putih dalam hutan, tandanya apa yang akan kita kerjakan bakal lancar'

Tatangar Banjar di atas menyebutkan tentang bila ketemu tikus putih dalam hutan menandakan kelancaran dalam bekerja. Tatangar tersebut menggambarkan masyarakat Banjar mengandalkan hutan sebagai tempat mencari nafkah. Mencari kayu bakar, hewan buruan, buah-buahan hutan biasa dilakukan untuk menambah pundi-pundi penghasilan.

Pada era modern, hutan di Kalimantan Selatan begitu memprihatinkan. Pembabatan hutan besar-besaran untuk menggali batu bara, dan dijadikan perkebunan kelapa sawit membuat hutan di Kalimantan Selatan terluka parah. Perusahaan besar pengeruk batu bara telah merusak keperawanan hutan Kalimantan Selatan. Belum lagi kemunculan perusahaan penanaman sawit yang melakukan penanaman sawit besar-besaran di bumi Kalimantan Selatan. Kelapa sawit merupakan tanaman rakus yang akan mengeruk kesuburan tanah dan sumber air tanah. Sungguh berbahaya jika ini dibiarkan terus menerus. Wajar bila musim penghujan tiba, bahaya Banjir mengintai dan tidak bisa dihindari. Sedangkan jika kemarau, matahari menyengat terik membuat sumber air menguap tak bersisa.

\section{Sistem Kepercayaan}

Tatangar berikut berhubungan dengan sistem kepercayaan masyarakat Banjar, misalnya kapidaraan sebagai sakit non medis.

Bila kakanakan garing panas tapi hujung talinganya dingin banar, tandanya kapidaraan

'Bila anak-anak sakit panas tetapi ujung telingnya dingin, tandanya kapidaraan

Dalam tatangar di atas bila anak-anak sakit panas, tetapi ujung telinganya dingin itu tanda kapidaraaan. Kapidaraan yang dimaksud dalam tatangar di atas adalah sakit non medis yang menurut kepercayaan masyarakat setempat disebabkan oleh gangguan pidara. Sebutan pidara ditujukan kepada ruh keluarga yang diduga mengganggunya. Kepidaraan biasanya diobati oleh perempuan paruh baya yang membaca basmalah, salawat, kemudian membaca mantra pidara ditiupkan pada kunyit bercampur kapur sirih ditusuk-tusuk lalu diusap ke anak-anak yang sakit tersebut pada saat matahari turun (Daud, 1997:417).

\section{Sistem Organisasi sosial/Pranata Sosial}

Masyarakat Banjar sebagian besar beragama Islam. Oleh karenanya, pranata sosialnya banyak mengacu pada aturan agama Islam. Hal tersebut dapat dilihat pada tatangar berikut.

Hayam jagau bangkungkuuk tangah malam, tandanya ada urang nang batianan di luar nikah 
'Ayam jago berkokok tengah malam, tandanya ada orang yang hamil di luar nikah'

Tatangar tersebut memaparkan tentang ayam jago yang berkokok tengah malam menandakan ada perempuan hamil di luar nikah. Secara logika memang tidak bisa ditemukan hubungan antara ayam berkokok dengan tanda perempuan hamil di luar nikah. Namun, tatangar tersebut menunjukkan pranata masyarakat Banjar. Pranata masyarakat Banjar pada tatangar tersebut mengenai anggapan buruk apabila hamil di luar nikah. Hamil di luar nikah berarti berzina. Berzina merupakan dosa besar dalam ajaran Islam. Oleh karenanya, hamil di luar nikah dianggap memalukan dan tercela bagi keluarga maupun masyarakat di sekitarnya.

Pranata masyarakat Banjar yang lain, misalnya mengenai perbuatan suka meminta-minta. Berikut kutipan tatangar Banjar .

Bila baisi tahi lalat di talapak tangan

kiwa, tandanya katuju bapipinta

'Bila mempunyai tahi lalat di telapak kiri, tandanya suka meminta-minta'

Tatangar Banjar di atas mengenai bila mempunyai tahi lalat di telapak kiri, menandakan suka meminta-minta. Memang belum bisa dibuktikan tatangar tersebut. Namun, tatangar tersebut menunjukkan sikap masyarakat yang mencela perbuatan orang yang suka meminta-minta. Meminta apapun itu, baik suka meminta makan, baju, atau meminta uang. Sikap memberi lebih mulia daripada meminta-minta.

Tatangar tersebut sekaligus menunjukkan adanya nilai kearifan lokal mengenai hubungan dengan sesama manusia. Perbuatan suka meminta-minta dianggap hina. Orang suka meminta minta tentu sering dijauhi dalam pergaulan. Oleh karenanya, para orang tua selalu mengajarkan anaknya sejak dini untuk lebih suka memberi daripada meminta-minta.

\section{Sistem Perlindungan/rumah}

Rumah merupakan tempat tinggal. Sebelum membangun rumah diperhatikan lebih dahulu tata letaknya, dan posisinya. Setelah rumah dibangun, sebaiknya diperhatikan kebersihannya. Hal-hal mengenai rumah/tempat tinggal menjadi perhatian penting dalam tatangar Banjar. Berikut kutipannya.

Bila ada balambika, tanda rumah badiri dibakas kuburan

'Bila ada balambika, tanda rumah berdiri di bekas kuburan'

Tatangar di atas memaparkan tentang bila ada balambika menandakan rumah berdiri di bekas kuburan. Tatangar tersebut memperingatkan masyarakatnya untuk berhati-hati sebelum mendirikan rumah. Jangan sampai membangun rumah dibekas kuburan karena akan menimbulkan ketidaknyamanan penghuninya. Ketidaknyamanan akibat tidak memperhatikan lokasi rumah yang akan dibangun dapat juga berupa adanya balambika, yaitu tanah merah menggunung dan semakin tinggi yang konon akibat adanya rumah rayap. Oleh karenanya, orang tua dahulu memperingatkan untuk memperhatikan lokasi sebelum membangun rumah demi kenyamanan penghuninya.

Tatangar berikut masih berkaitan dengan rumah. Berikut kutipannya. 
Bila kelalawar masuk rumah, tandanya ada urang nang handak baniat jahat

'Bila kelelawar masuk ke dalam rumah, tandanya ada orang yang berniat jahat'

Tatangar di atas mengenai bila kelelawar masuk ke dalam rumah menandakan ada orang yang berniat jahat. Tatangar tersebut mengingatkan masyarakat Banjar untuk menjaga rumah dari binatang-binatang liar, contohnya adalah kelelawar. Sebenarnya, tidak ada hubungannya antara kelelawar masuk dengan orang yang berniat jahat. Hal tersebut lebih kepada peringatan kepada penghuni rumah terhadap dampak negatif dari masuknya kelelawar.

\section{Sistem Makan/kuliner}

Beragam kuliner ada di Kalimantan Selatan, dari makanan pokok, berbagai bahan makanan, sayur, ikan, dan kuekue tradisional. Keragaman kuliner di Kalimantan Selatan dapat di lihat pada tatangar Banjar. Berikut kutipannya.

'Bermimpi makan wadai apam, tandanya dapat harta

'Bermimpi makan kue apam, tandanya dapat harta'

Tatangar di atas mengatakan apabila bermimpi makan kue apam menandakan dapat harta. Sebenarnya, tidak dapat dibuktikan ilmiah antara apabila mimpi makan apam dengan mendapat harta. Namun, dapat diketahui salah satu kuliner khas Banjar, yaitu kue apam. Kue apam sangat nikmat dan sampai sekarang masih tetap ada di kehidupan masyarakat Banjar.

Dalam tatangar, dapat diketahui bahwa makanan pokok masyarakat
Banjar nasi dari beras yang sudah dimasak. Berikut kutipannya.

Amun baras dihurung samut, sangkaannya harga baras cagar naik

'Bila beras dikerubuti semut, pertanda harga beras bakal naik'

Tatangar di atas memaparkan tentang beras apabila dikerubuti semut, menandakan harga beras akan naik. Dari segi logika, memang tidak bisa dibuktikan antara beras yang dikerubuti semut dengan harga beras yang naik. Namun, tatangar tersebut menunjukkan kedudukan beras yang sangat penting. Hal tersebut karena beras merupakan makanan pokok bagi masyarakat Banjar. Wajar, apabila harga beras naik akan membuat kekhawatiran bagi masyarakatnya.

\section{Kesenian}

Tatangar berikut mengungkapkan tentang tarbang atau rabana dalam salah satu alat musik kesenian yang dipergunakan oleh masyarakat Banjar. Berikut kutipannya.

Bila bamimpi mandangar atau malihat urang mamainakan tarbang, tandanya handak mandapat kasanangan dalam hidup

'Bila bermimpi mendengar atau melihat orang memainkan rebana, tandanya akan mendapat kesenangan dalam hidup'

Tatangar di atas memaparkan mengenai apabila mimpi mendengar atau melihat orang memainkan rebana menandakan akan mendapat kesengangan dalam hidup. Tatangar tersebut menunjukkan penggunaan rebana sebagai alat musik kesenian dalam masyarakat Banjar. Penggunaan alat musik rebana masih dipergunakan hingga saat ini. Misalnya, rebana 
digunakan sebagai iringan madihin, bahabsyi/pembacaan salawat kepada Rasullah, dan iringan balamut. Apabila alat musik rebana ini mengiringi berbagai kesenian tradisional ini akan menimbukan rasa senang bagi orang yang mendengarkannya.

Keberadaan rebana dalam hal kesenian merupakan salah satu kearifan lokal dalam masyarakat Banjar mengenai hubungan antar sesama manusia.

\section{Sistem Daur Hidup}

Sistem Daur hidup yang ditemukan dalam tatangar Banjar, meliputi perkawinan, saat hamil, bayi/anakanak, dan kematian.

\section{a. Perkawinan}

Tatangar yang berkaitan dengan perkawinan dapat disimak melalui kutipan berikut.

Bamasak kamasinan, tanda handak kawin

Memasak keasinan, tandanya mau kawin'

Tatangar tersebut memaparkan apabila saat memasak keasinan menandakan yang memasak berkeinginan untuk kawin. Tatangar tersebut sampai sekarang masih bertahan dalam masyarakat Banjar. Sering kali, apabila ada seseorang yang masakannya keasinan terutama perempuan dikatakan akan kawin. Tatangar tersebut sebagai pancingan orang tua zaman dahulu untuk mengetahui kesiapan anak gadisnya untuk menikah. Hal tersebut karena anak gadis biasanya dikenal sangat pemalu mengungkapkan perasaan, terlebih keinginan untuk menikah.
Tatangar tesebut mengandung nilai kearifan lokal mengenai hubungan manusia dengan sesama manusia. Dalam perkawinan, hubungan dua orang manusia yang berlainan jenis dipersatukan yang diakui oleh masyarakatnya. Perkawinan menurut masyarakat Banjar sebagai ikatan suci untuk menyempurnakan ajaran agama. Melalui perkawinan, sebuah keluarga kecil akan terbentuk. Baik buruknya suatu masyarakat ditentukan oleh keluarga kecil tersebut.

\section{b. Hamil}

Tatangar berikut merupakan pengetahuan kolektif, berupa perkiraan jenis kelamin janin berdasarkan bentuk perut sang ibu saat hamil. Simak tatangar berikut.

Parut babinian batianan kalihatan bulat, tandanya anak nang ditianakan babinian

'Perut perempuan hamil kelihatan bulat, tandanya anaknya perempuan'

Tatangar di atas memaparkan bahwa apabila perut perempuan hamil bentuknya bulat menandakan anaknya nanti berjenis kelamin perempuan. Tatangar tersebut merupakan pengetahuan kolektif berupa perkiraaan jenis kelamin janin berdasarkan bentuk perut sang ibu saat hamil. Pengetahuan kolektif tersebut masih dipercaya hingga saat ini. Pada saat sekarang, keakuratan mengetahui jenis kelamin janin dalam kandungan di dukung oleh teknologi yang biasa dikenal masyarakat dengan USG. Namun, kuasa Tuhan jua yang lebih utama menentukan kebenarannya sehingga perkiraan USG dapat juga meleset. 
Tatangar tersebut memiliki nilai kearifan lokal mengenai hubungan manusia dengan Tuhannya. Tatangar berkenaan dengan perkiraan manusia berdasarkan ciri fisik, tetapi semua terpulang pada ketetapan yang telah ditentukan Tuhan. Manusia sebagai makhluk ciptaannya haruslah menerima dengan penuh keikhlasan segala sesuatu yang telah digariskan oleh Tuhannya.

Kutipan berikut, kebalikan dari tatangar sebelumnya.

Parut babinian batianan kalihatan

lunjung atau maninggi, tandanya anak nang ditianakan lalakian

'Perut perempuan hamil kelihatan lonjong atau meninggi, tandanya anaknya laki-laki'

Tatangar di atas memaparkan apabila perut perempuan hamil lonjong, tandanya janinnya laki-laki. Apabila tatangar sebelumnya mencirikan tentang calon janin perempuan, tatangar ini mengenai calon janin laki-laki. Tatangar tersebut pengetahuan kolektif berupa perkiraaan jenis kelamin janin berdasarkan bentuk perut sang ibu saat hamil. Pengetahuan kolektif tersebut masih dipercaya hingga saat ini.

\section{c. Bayi/ anak-anak}

Tatangar-tatangar Banjar berikut mengenai daur hidup tahap bayi dan anak-anak.

Tang bayi mancigu, tandanya handak balamak atau baganal

'Tiba-tiba bayi cegukan, tandanya tubuhnya akan gemuk atau besar'

Tatangar berikut mengenai tiba-tiba bayi cegukan tandanya tubuhnya akan gemuk atau besar. Tatangar tersebut mengenai pengetahuan kolektif masyarakat Banjar mengenai bayi yang cegukan menandakan tubuhnya akan gemuk atau besar. Pengetahuan kolektif tersebut diperoleh turun menurun dari nenek sang bayi diberitahukan ke ibu sang bayi. Pengetahuan kolektif ini berguna untuk mengurangi kecemasan ibu bayi kepada cegukan yang dialami bayinya. Tatangar ini masih bertahan hingga saat ini di masyarakat Banjar.

Tatangar berikutnya berkenaan tanda keseleo pada anak-anak.

Bila kakanakan garing panas tapi talapak batis lawan talapak tangannya dingin, tandanya kasilahu.

Bila anak-anak sakit panas tapi telapak kaki dan tangannya dingin, tandanya keseleo'

Tatangar di atas mengenai anak-anak yang sakit panas tetapi telapak kaki dan tangannya dingin berarti menandakan ia keseleo. Tatangar ini biasanya secara turun menurun diwariskan ke generasi berikutnya terutama kepada perempuan yang memiliki anak. Jika anak keseleo, biasanya tidak mempan diberi obat penurun panas. Anak-anak yang keseleo, biasanya dibawa sang ibu ke dukun urut. Setelah di urut, biasanya sang anak akan sembuh dan ceria kembali.

\section{d. Kematian}

Kematian menyisakan kesedihan bagi yang ditinggalkan. Penanda kematian dalam tatangar sebagai isyarat kehati-hatian bagi yang ditinggalkan. Simak kutipan berikut.

Bila tang tadangar bunyi burung halang, tandanya ada kaluarga nang handak mati

‘Bila tiba-tiba terdengar bunyi burung elang, tandanya keluarga ada yang hendak meninggal'

Tatangar berikut mengatakan bahwa apabila tiba-tiba terdengar bunyi 
burung elang berarti menandakan keluarga ada yang hendak meninggal. Tatangar tersebut secara logika sulit dihubungkan dengan kenyataan. Namun, tatangar tersebut mengingatkan terhadap datangnya kematian. Kematian sebagai keniscayaan menimpa pada tiap-tiap yang bernyawa. Oleh karenanya, sangat baik untuk mengingat kematian.

Batang paring bacagat di tangah
banyu, tandanya ada urang mati
tinggalam
Batang bambu tegak di tengah air,
tandanya ada orang mati
tenggelam'

Tatangar di atas menandakan akan ada orang mati tenggelam apabila ada batang bambu tegak di tengah air. Tatangar tersebut secara ilmiah sulit untuk diterima akal. Namun, tatangar tersebut menunjukkan kentalnya nuansa sungai pada masyarakat Banjar tempo dulu. Sungai memegang peranan penting bagi jalur transportasi. Sungai juga sebagai alat nadi perekonomian dan sumber kehidupan.

Sungguh disayangkan, sungai di Kalimantan Selatan kini sangat menyedihkan. Sungai-sungai besar menyempit menjadi sebuah selokan. Abrasi, pencemaran, dan pendangkalan sungai kian menjadi. Sungai dijadikan tempat sampah praktis bagi limbah rumah tangga dan pabrik. Kota seribu sungai mungkin hanya tinggal kenangan karena sungai telah mengering dan hilang tertimbun sampah.
Kearifan lokal dari tatangar di atas mengenai hubungan antara manusia dan lingkungan alam dalam hal ini sungai. Menghidupkan kembali nilainilai kearifan lokal mengenai kesadaran akan pentingnya sungai semestinya menjadi peer penting untuk masyarakat Banjar. Mencintai sungai di mulai dari lingkungan keluarga terlebih dahulu dan semestinya didukung oleh pemerintah daerah sebagai penggerak utama. Sungai sumber kehidupan karenanya cintailah sungai!

\section{PENUTUP}

Berdasarkan analisis di atas, disimpulkan bahwa tatangar Banjar memiliki suatu sistem kognisi yang mengkonstruksi pola hidup dan pola pikir masyarakat Banjar sebagai pemilik tradisi lisan tersebut. Hal tersebut muncul dari sebuah pengalaman yang menjadi sebuah pengetahuan kolektif sebagai bagian kearifan lokal masyarakat Banjar. Tatangar Banjar sebagai ekspresi sistem kognisi ditunjukkan dari sistem mata pencaharian, kepercayaan, organisasi sosial atau pranata sosial, perlindungan, makanan atau kuliner, kesenian, dan daur hidup yang ada pada masyarakat Banjar.

Semoga penelitian sederhana ini, menumbuhkan kesadaran pentingnya melestarikan tradisi lisan Banjar dan terus berusaha untuk terlibat dalam usaha pelestarian lingkungan alam. 
Undas Vol 12. , Nomor 1, Juni 2016 : 97--109

\section{DAFTAR PUSTAKA}

Danandjaja, James. 1982. Folklor Indonesia. Jakarta.Grafiti

. 1998. Pendekatan Folklor dalam Penelitian Bahan-Bahan Tradisi Lisan. Pudentia MPSS (Ed), Metodelogi Kajian Tradisi Lisan . Jakarta:Yayasam Obor dan Yayasan ATL.

Daud, Alfani. 1997. Islam dan Masyarakat Banjar: Deskripsi dan Analisa Kebudayaan Banjar. Jakarta: PT Raja Grasindo Persada.

Hapip, Abdul Djebar. 1997. Kamus Bahasa Banjar-Indonesia. Banjarmasin. PT Grafika Wangi Kalimantan.

Hatmiati. 2016. "Revitalisasi Pamali dalam Tradisi Lisan Orang Banjar." Dalam Seminar Budaya. Banjarbaru(tidak diterbitkan)

Hirmawan, Yudi Handoko. 2013."Lelaq sebagai Cermin Sistem Kognisis Masyarakat Sasak" dalam Proseding Seminar Internasional. Yogyakarta: Fakultas Ilmu Budaya UGM dan Gress Publishing.

Ideham, Suriansyah. M., dkk. 2005. Urang Banjar dan Kebudayaannya. Banjarmasin: PT. Grafika Wangi Kalimantan.

Alwi, Hasan, dkk. 2002. Kamus Besar Bahasa Indonesia Edisi Ketiga. Jakarta:Balai Pustaka.

Moleong, Lexy J. 2002. Metodologi Penelitian Kualitatif. Bandung: PT. Rosda.

Mugeni. Muhammad,dkk.. 2008. Kamus Bahasa Banjar Hulu-Indonesia. Banjarmasin: Balai Bahasa Banjarmasin.

Murniah, Dad. 2013. "Sirkumologi dalam Folklor Indonesia sebagai dasar Pembangunan Bangsa" dalam Folklor dan Forklife. Yogyakarta: Ombak.

Pudentia MPSS. 2007. Hakikat Kelisanan dalam Tradisi Lisan Melayu Mak Yong. Depok: Fakultas Ilmu Pengetahuan Budaya Universitas Indonesia.

Saputra, Heru S.P. 2013. “Bahasa Mantra Karakteristik Kelisanan, Identitas Kultural Anganangan Kolektif Orang Using." dalam Proseding Seminar Internasional. Yogyakarta: Fakultas Ilmu Budaya UGM dan Gress Publishing.

Turmuzi, Ahmad. 2011. Perspektif Folklor dalam Kehidupan Masyarakat Modern. Diunduh tanggal 1 September 2016 dalam http//Sejarah.Kompasiana.Com. 2011/12/05/Persfektif. Folklor dalam. Kehidupan. Masyarakat. Modern.

Yayuk, Rissari, dkk. 2009. Tatangar atau Wahana Banjar. Banjarbaru: Balai Bahasa Banjarmasin. 
Tatangar Banjar Sebagai Ekspresi Sistem Kognisi Masyarakat Banjar (Sri Wahyu Nengsih)

2010. “Tatangar Banjar" dalam Bunga Rampai Hasil Penelitian Sastra. Banjarbaru: Balai Bahasa Banjarmasin. 